\title{
PENGARUH PUPUK BIORGANIK DAN PUPUK BOOM FLOWER TERHADAP PERTUMBUHAN DAN HASIL TANAMAN TERUNG (Solanum melongenaL) VARIETAS LAGUNA F1.
}

\author{
Rio Anggara ${ }^{1}$, dan Abdul Fatah ${ }^{2}$ \\ ${ }^{1}$ Agroteknologi, Fakultas Pertanian, Universitas 17 Agustus 1945 Samarinda, Indonesia. \\ ${ }^{2}$ Dosen Fakultas Pertanian, Universitas 17 Agustus 1945 Samarinda 75124, Indonesia. \\ E-Mail: rio.an66ara@gmail.com; fatah@untag-smd.ac.id
}

\begin{abstract}
ABSTRAK
Pengaruh Pupuk Biorganik dan Pupuk Boom Flower Terhadap Pertumbuhan dan Hasil Tanaman Terung (Solanum Melongena L.) Varietas Laguna F1. Tujuan penelitian untuk mengetahui pengaruh pemberian pupuk Biorganik dan pupuk Boom Flower serta interaksinya terhadap pertumbuhan dan hasil tanaman Terung, serta untuk mengetahui konsentrasi pupuk Biorganik dan pupuk Boom Flower yang tepat terhadap pertumbuhan dan hasil tanaman Terung.

Penelitian menggunakan Rancangan Acak Lengkap (RAL), dalam percobaan faktorial 4 x 3, dengan 4 ulangan. Terdiri atas 2 faktor perlakuan. Faktor I adalah pupuk Biorganik (P), terdiri atas 4 taraf, yaitu : $\mathrm{p}_{0}=$ tanpa pupuk biorganik (kontrol), $\mathrm{p}_{1}=$ dosis pupuk biorganik $25 \mathrm{~g} /$ polibag, $\mathrm{p}_{2}=$ dosis pupuk biorganik 50 $\mathrm{g} /$ polibag, $\mathrm{p}_{3}=$ dosis pupuk biorganik $75 \mathrm{~g} /$ polibag. Faktor II adalah pupuk Boom Flower (B), terdiri atas 3 taraf, yaitu : $b_{0}=$ tanpa pupuk Boom Flower (kontrol), $b_{1}=$ konsentrasi pupuk boom flower 2 ml liter air ${ }^{-1}, b_{2}$ $=$ konsentrasi suplemen boom flower $4 \mathrm{ml}$ liter air $^{-1}$.

Perlakuan pupuk biorganik tidak berpengaruh nyata terhadap umur saat berbunga. Berpengaruh sangat nyata terhadap tinggi tanaman umur 15 hari, umur 30 hari dan umur 45 hari setelah tanam, jumlah buah per tanaman dan berat buah per tanaman. Berat buah per tanaman terberat terdapat pada perlakuan $\mathrm{p}_{3}$ (dosis pupuk $75 \mathrm{~g} /$ polibag), yaitu 3,31 kg/tanaman. Sedangkan berat buah teringan terdapat pada perlakuan $\mathrm{p}_{0}$ (tanpa pupuk biorganik), yaitu $1,84 \mathrm{~kg} /$ tanaman.

Perlakuan pupuk boom flower tidak berpengaruh nyata terhadap tinggi tanaman umur 30 hari dan umur 45 hari setelah tanam. Berpengaruh nyata terhadap tinggi tanaman umur 15 hari setelah tanam dan jumlah buah per tanaman. Berpengaruh sangat nyata terhadap umur saat berbunga dan berat buah per tanaman. Berat buah per tanaman terberat terdapat pada perlakuan $b_{2}$ (konsentrasi pupuk $4 \mathrm{ml} \mathrm{liter} \mathrm{air}{ }^{-1}$ ), yaitu 2,79 kg/tanaman. Sedangkan berat buah teringan terdapat pada perlakuan $b_{0}$ (tanpa pupuk boom flower), yaitu 2,44 $\mathrm{kg} /$ tanaman.

Interaksi perlakuan pupuk biorganik dan pupuk boom flower tidak berpengaruh nyata terhadap tinggi tanaman umur 15 hari, umur 30 hari dan umur 45 hari setelah tanam, umur saat berbunga dan jumlah buah per tanaman. Berpengaruh nyata terhadap berat buah per tanaman.
\end{abstract}

Kata kunci : Pupuk biorganik, Pupuk boom flower, Pertumbuhan, tanaman terung.

\begin{abstract}
The Influence of Biorganik Fertilizer and Boom Flower Fertilizer on the Growth and Results of Eggplant (Solanum melongena L.) Laguna F1 Variety. The purpose of this research is to study the effect of Biorganik fertilizer and Boom Flower fertilizer and its interaction on the growth and yield of Eggplant, and to obtain the proper concentration of Biorganik fertilizer and Boom Flower fertilizer for the growth and yield of Eggplant.

It used Completely Randomized Design (RAL), in a $4 \times 3$ factorial experiment, with 4 replications. The research consisted of 2 factors of treatment. Factor I is a Biorganik fertilizer dosage (P), consisting of 4 levels, namely: $p_{0}=$ no biorganik fertilizer application (control), $p_{1}=25 \mathrm{~g} /$ polybag, $p_{2}=50 \mathrm{~g} /$ polybag, $p_{3}=$ $75 \mathrm{~g} /$ polybag. Factor II is Boom Flower fertilizerconcentration (B), consisting of 3 levels, namely: b0 = no Boom Flower fertilizer application (control), $b 1=2 \mathrm{ml}$ liter water $^{-1}, b_{2}=4 \mathrm{ml}_{\text {liter }}$ water ${ }^{-1}$.

The treatment of biorganik fertilizer had no significant effect on the age of crop flowered. It affected very significantly on the plant height at 15 days, 30 days and 45 days after planting, the number of fruit per plant and weight of fruit per plant. The heaviest fruit weight per plant was found at the treatment of $p_{3}(75$
\end{abstract}


$\mathrm{g} /$ polybag), ie $3.31 \mathrm{~kg} /$ plant. While the lightest fruit weight was found at the control treatment or $p_{0}$ (no biorganikfertilizer application), which is $1.84 \mathrm{~kg} /$ plant.

Treatment of boom flower fertilizer did not significantly affect on the plant height at 30 days and 45 days after planting. But it affected significantly on the plant height at 15 days after planting and number of fruit per plant. And it affected very significantly on the age of crop flowered and weight of fruit per plant. The heaviest fruit weight per plant was found in the treatment of $b_{2}$ (concentration of fertilizer 4 ml liter water ${ }^{-1}$ ), ie $2.79 \mathrm{~kg} / \mathrm{plant}$. While the lightest fruit weight wasfound in the treatment of $b_{0}$ (no boom flower fertilizer application), which is $2.44 \mathrm{~kg} /$ plant.

The interaction treatment between biorganik fertilizer and boom flower fertilizer had no significant effect on the plant height at 15 days, 30 days and 45 days after planting, age at crop flowered and number of fruit per plant. But it had significant effect on the weight of fruit per plant.

Key words : Biorganik Fertilizer, Boom Flower Fertilizer, Eggplant, Growth.

\section{PENDAHULUAN}

Terung (Solanum melongenaL) merupakan salah satu komoditas pertanian yang penting dan dibutuhkan di Indonesia, hal ini disebabkan karena terung mempunyai kandungan gizi cukup lengkap dan mempunyai nilai ekonomis tinggi. Terung biasanya digunakan sebagai bahan makanan, bahan terapi, dan bahan kosmetik alami. Buah ini banyak mengandung kalium dan vitamin A yang dapat berguna bagi tubuh. Komposisi kimia terung per 100 gram yaitu air 92,70 gram; abu (mineral) 0,60 gram; besi 0,60 mg; karbohidrat 5,70 gram; lemak 0,20 gram; serat 0,80 gram; kalori $24,00 \mathrm{kal}$; fosfor $27,00 \mathrm{mg}$; kalium 223,00 mg; kalsium 30,00 mg; protein 1,10 gram; natrium $4,00 \mathrm{mg}$; vitamin B3 0,60 mg; vitamin B2 0,05 mg; vitamin B1 $10,00 \mathrm{mg}$; vitamin A $130,00 \mathrm{SI}$; dan vitamin C 5,00 mg Direktorat Gizi (Budiman, 2008).

Tanaman terung merupakan salah satu sayuran yang cukup popular dan digemari oleh seluruh lapisan masyarakat. Buah terung yang masih muda selain enak untuk dijadiakan sayuran dan lalapan, juga mengandung gizi yang cukup tinggi dan komposisinya lengkap sehingga komoditas terung sangat potensial untuk dikembangkan secara intensif dalam skala agribisnis sekaligus menyumbang cukup besar terhadap keanekaragaman pangan bergizi bagi penduduk (Rukmana, 2006).
Selain itu Terung memiliki nilai ekonomis dan sosial yang tinggi. Produksi terung tidak hanya berlaku di pasaran dalam negeri (domestik), tetapi juga sudah menjadi mata dagang ekspor. Bentuk produk yang sudah menembus pasar ekspor adalah " Terung Asinan “ (Rukmana, 2006). Distribusi pemasarannya tidak hanya di lakukan di pasar-pasar tradisional saja, namun juga di supermarket ataupun toko-toko swalayan (Samadi 2011). Selain itu kemajuan di bidang dalam pengolahan hasil pertanian yang semakin berkembang dapat memperluas pemasaran terung, misalnya manisan dan asinan terung. Oleh sebab itu, komoditas terung sangat potensial untuk dikembangkan secara intensif (Rukmana, 2006). Di daerah Kalimantan Timur, pengusahaan tanaman terung sudah sejak lama dilakukan. Produksi terung tahun 2015 mencapai 9.901 Ton (BPS Kaltim, 2015). Secara umum produktivitas tanaman Terung masih tergolong rendah, hal tersebut dapat disebabkan oleh beberapa faktor yaitu teknik budidaya yang dilakukan petani yang belum intensif, faktor iklim dan tingkat kesuburan tanah yang rendah. Usaha yang dapat dilakukan untuk meningkatkan produksi tanaman sayuran tersebut salah satu diantaranya dengan pemberian pupuk. Pemupukan dilakukan dengan cara memberikan pupuk. Untuk memenuhi kebutuhan unsur hara dapat dilakukan dengan cara melakukan 
pemupukan menggunakan pupuk organik (Marsono dan Lingga, P. 2006).

Pupuk terbagi dua kelompok bedasarkan bentuk pupuk yaitu pupuk padat dan pupuk cair. Pupuk padat dalam aplikasinya sebagian besar dilakukan dengan cara pemberian pada tanah dan untuk penyerapan pada tanaman membutuhkan waktu untuk dimanfaatkan dalam proses fotosintesis. Pemberian pupuk kebanyakan dilakukan melalui tanah, namun cara tersebut mempunyai beberapa kelemahan, diantaranya adalah unsur hara menjadi tidak tersedia karena dapat mengalami pencucian, penguapan dan terfiksasi (diikat) oleh partikel tanah atau misel tanah (Sarief, 1989). Untuk mengatasi hal tersebut pemberian pupuk dapat dilakukan melalui tubuh tanaman atau dikenal dengan istilah pupuk daun. Kelebihan yang diperoleh dari pemberian pupuk melalui daun adalah pada umumnya mengandung unsur hara yang lengkap terdiri atas unsur makro dan unsur mikro, unsur hara lebih cepat larut sehingga cepat diserap tanaman. Pupuk cair aplikasinya dapat langsung disemprotkan pada bagian tanaman, terutama pada bagian daun yang mana pada bagian daun tersebut terdapat stomata yang merupakan tempat proses fotosintesis, sehingga dalam penyediaan unsur hara pada tanaman dapat tercukupi dalam waktu singkat (Agromedia, 2007). Kebutuhan unsur hara juga dapat dipenuhi dengan cara melakukan pemupukan menggunakan pupuk organik (Marsono, 2006).

Berdasarkan uraian diatas maka dilakukan penelitian untuk mengetahui pengaruh pemberian pupuk Boom Fower dan pupuk biorganik terhadap pertumbuhan dan hasil tanaman Terung (Solanum melongena L). Tujuan Penelitian adalah untuk mengetahui pengaruh pemberian pupuk Biorganik dan suplemen Boom Flower serta interaksinya terhadap pertumbuhan dan hasil tanaman Terung. Untuk mengetahui konsentrasi pupuk Biorganik dan suplemen Boom Flower yang tepat terhadap pertumbuhan dan hasil tanaman Terung.

\section{METODA PENELITIAN}

\subsection{Tempat dan Waktu}

Tempat penelitian di PT Multi Pacific International Cipta Graha Estate Pondok III Desa Bumi Jaya, Kecamatan Kaubun, Kabupaten Kutai Timur. Pada bulan Februari-Mei 2018.

\subsection{Bahan dan Alat}

Bahan yang digunakan adalah benih tanaman Terung (Varietas Laguna F1), pupuk Biorganik, suplemen tanaman Boom Flower, pupuk kandang, topsoil, Furadan 3 G, dan polibag $35 \mathrm{~cm} \times 45 \mathrm{~cm}$.

Alat yang digunakan adalah cangkul, sabit, timbangan, pisau, kamera, hand sprayer, karung plastik, meteran, kertas, tali rafia, sarlon, dan alat tulis.

\subsection{Rancangan Penelitian}

Penelitian menggunakan Rancangan Acak Lengkap (RAL) dengan pola faktorial 4 x 3 yang diulang sebanyak 4 kali. Faktor - faktor perlakuan, yaitu:

Faktor dosis pupuk biorganik (P) yang terdiri dari 4 taraf, yaitu:

$\mathrm{p}_{0}=$ tanpa pupuk biorganik (kontrol) $\mathrm{p}_{1}=$ dosis pupuk biorganik 25 g polibag $^{-1} \mathrm{p}_{2}=$ dosis pupuk biorganik $50 \mathrm{~g}$ polibag $^{-1} \mathrm{p}_{3}$ $=$ dosis pupuk biorganik $75 \mathrm{~g}$ polibag $^{-1}$

Faktor pupuk boom flower (B) yang terdiri dari 3 taraf, yaitu :

$\mathrm{b}_{0}=$ tanpa pupuk boom flower (kontrol) $b_{1}=$ konsentrasi pupuk boom flower $2 \mathrm{ml}$ liter air $^{-1} \mathrm{~b}_{2}=$ 
konsentrasi pupuk boom flower $4 \mathrm{ml}$ liter air ${ }^{-1}$
Kombinasi perlakuan dalam penelitian yang akan dilaksanakan sebagai berikut:

Tabel 1. Kombinasi Perlakuan

\begin{tabular}{cccc}
\hline Perlakuan & $\mathrm{b}_{0}$ & $\mathrm{~b}_{1}$ & $\mathrm{~b}_{2}$ \\
\hline $\mathrm{p}_{0}$ & $\mathrm{p}_{0} \mathrm{~b}_{0}$ & $\mathrm{p}_{0} \mathrm{~b}_{1}$ & $\mathrm{p}_{0} \mathrm{~b}_{2}$ \\
$\mathrm{p}_{1}$ & $\mathrm{p}_{1} \mathrm{~b}_{0}$ & $\mathrm{p}_{1} \mathrm{~b}_{1}$ & $\mathrm{p}_{1} \mathrm{~b}_{2}$ \\
$\mathrm{p}_{2}$ & $\mathrm{p}_{2} \mathrm{~b}_{0}$ & $\mathrm{p}_{2} \mathrm{~b}_{1}$ & $\mathrm{p}_{2} \mathrm{~b}_{2}$ \\
$\mathrm{P} 3$ & $\mathrm{p} 3 \mathrm{~b} 0$ & $\mathrm{p} 3 \mathrm{~b} 1$ & $\mathrm{p} 3 \mathrm{~b} 2$ \\
\hline
\end{tabular}

Setiap kombinasi perlakuan diulang sebanyak 4 kali, sehingga jumlah satuan penelitian menjadi 4 x 3 x $4=48$ polibag.

\subsection{Pelaksanaan Penelitian}

Persiapan Lahan

Lahan berukuran $10 \mathrm{~m} \quad \mathrm{x} 15 \mathrm{~m}$ dibersihkan dari kotoran dan gulma untuk memudahkan pada saat meletakkan polibag.

Penyemaian Benih

Beberapa hal yang perlu diperhatikan dalam penyemaian benih terung adalah sebagai berikut: seleksi benih, peredaman benih dalam air hangat dan desinfektan selama 12 jam, pemeraman benih 1-2 hari, dalam waktu 1-2 hari benih sudah mulai berkecambah. Benih yang sudah berkecambah dapat dipindahkan ke pesemaian (kantong plastik atau kotak bedengan), apabila akar benih telah mencapai panjang $2 \mathrm{~mm}-3 \mathrm{~mm}$.

Penanaman/Penyemaian Benih

Benih-benih yang telah berkecambah harus segera dipindahkan atau disemaikan ke dalam kantong plastik atau kotak bedengan yang sudah disiapkan. Penyemaian benih dilakukan dengan cara sebagai berikut:

a. Media semai atau tempat pesemaian dibasahi terlebih dahulu sampai air meresap ke bagian dasar. Penyiraman media semaian sebaiknya dilakukan sehari sebelum benih disemai.

b. Dibuat lubang tanam sebesar pensil pada kantong atau kotak bedengan, dengan kedalam sekitar $1 \mathrm{~cm}$.

c. Benih yang telah berkecambah dimasukkan ke dalam lubang tanam dengan menggunakan pinset, dengan posisi miring atau agak tidur.

d. Benih ditimbun dengan media tanah yang sama, maksimal setinggi $1 \mathrm{~cm}$. Penimbunan yang terlalu dalam dapat menggagalkan pertumbuhan benih.

e. Penanaman pada kotak harus memperhatikan jarak tanam. Jarak tanam pada penanaman benih di kotak bedengan adalah $10 \mathrm{~cm} \times 10 \mathrm{~cm}$.

f. Setelah benih ditanam, media semai dibasahi dengan air secukupnya.

Pemeliharaan benih 
Benih yang telah yang telah ditanam harus dipelihara secara intensif selama awal pertumbuhan, sampai tanaman atau bibit dapat dipindah ke polibag. Waktu yang diperlukan untuk memelihara bibit sampai dapat dipindahkan ke polibag adalah sekitar tiga minggu, atau tepatnya 21 hari setelah penyemaian.

Pemeliharaan bibit di persemaian sampai dapat dipindahkan ke polibag meliputi kegiatan-kegiatan sebagai berikut: penyiraman, pengaturan naungan, penyiangan, penanaman, penyiangan.

Penanaman

Penanaman dilakukan setelah bibit Terung Varietas Laguna F1 berumur tiga minggu setelah semai media tanam yang digunakan berupa campuran topsoil dan pupuk kandang dengan perbandingan 2:1.

Pemberian Pupuk

Aplikasi perlakuan pupuk biorganik dilakuan pada saat persiapan lahan seminggu sebelum tanam, dengan cara ditaburkan kedalam media tanam sesuai dengan taraf dan konsentrasi perlakuan. Aplikasi perlakuan suplemen Boom Flower dilakukan dengan interval 2 minggu sekali, pada umur tanaman 14, 28, dan 42 hari setelah tanam (HST), dengan cara disemprotkan di seluruh bagian tanaman sesuai dengan taraf dan konsentrasi perlakuan. Penyemprotan dilakukan di sore hari.

Pemasangan Ajir

Pemasangan ajir dengan panjang \pm $100 \mathrm{~cm}$ dilakukan setelah tanaman berumur dua minggu setelah tanam.

Pemeliharaan
a. Penyiraman

Penyiraman dilakukan setiap pagi dan sore hari sesuai dengan keadaan curah hujan.

b. Penyiangan

Penyiangan dilakukan 7 hari sekali secara manual menggunakan tangan dan cangkul untuk sekitar lahan penelitian.

c. Pewiwilan

Pewiwilan bertujuan untuk merangsang pertumbuhan tunastunas baru serta bunga dan dilakukan 2 minggu setelah tanam secara manual menggunakan tangan pada cabang ketiak daun.

\section{Panen}

Panen dilakukan pada saat Terung Varietas Laguna F1 sudah berwarna ungu dengan umur 45-60 HST, pemanenan dilakukan sebanyak 4 kali dengan interval seminggu sekali.

\subsection{Pengamatan dan Pengambilan Data}

Tinggi Tanaman $(\mathrm{cm})$

Tinggi tanaman diukur pada saat tanaman berumur 15, 30, dan 45 HST. Pengukuran tinggi tanaman dilakukan $2 \mathrm{~cm}$ dari permukaan tanah yang telah diberi tanda pada bagian pangkal tanaman yang bersentuhan dengan tanah sampai dengan titik tumbuh cabang utama tanaman yang diteliti.

Umur Saat Berbunga (hari)

Dihitung sejak mulai bibit dipindah ke dalam polibag sampai dengan munculnya bunga pertama kali.

Jumlah Buah Per Tanaman (buah) Dihitung jumlah buah per tanaman setiap panen dan dijumlahkan sampai 4 kali panen.

Berat Buah Per Tanaman (kg)

Dengan menimbang berat buah segar per tanaman pada setiap kali 
panen dan dijumlahkan beratnya, dari panen pertama sampai panen keempat \& dirataratakan

\subsection{Analisis Data}

Untuk mengetahui pengaruh perlakuan pupuk Biorganik dan Pupuk Boom Flower serta interaksinya, maka data hasil pengamatan dianalisis dengan Sidik Ragam menurut Steel dan Torrie, (1991).
Bila hasil sidik ragam berpengaruh nyata (F.hitung $>\mathrm{F}$ table 5\%) atau berpengaruh sangat nyata (F.hitung > $\mathrm{F}$ table 1\%), maka untuk membandingkan dua rata - rata perlakuan dilakukan uji lanjutan dengan uji Beda Nyata Terkecil (BNT) taraf nyata 5\%, sedangkan bila tidak berpengaruh nyata ( $\mathrm{F}$ hitung $\leq \mathrm{F}$ table 5\%) tidak dilakukan uji lanjutan. Rumus uji BNT sebagai berikut:

$$
\mathrm{BNT}=\text { nilai } \mathrm{t}-\text { table } \mathrm{x} \sqrt{ } 2 \mathrm{KTgalat} / \mathrm{r}
$$

Keterangan:

$\mathrm{T}-$ tabel $=$ nilai $\mathrm{t}$ pada tabel $\mathrm{T}(\alpha=5 \%$, nilai derajat bebas galat $)$

KT galat = kuadrat tengah galat

$\mathrm{r}$ = banyaknya ulangan

\section{HASIL PENELITIAN DAN PEMBAHASAN}

\subsection{Tinggi Tanaman Umur 15 Hari Setelah Tanam}

Hasil sidik ragam menunjukkan bahwa perlakuan pupuk biorganik (P) berpengaruh sangat nyata, dan perlakuan pupuk boom flower (B) berpengaruh nyata, sedangkan interaksinya $(\mathrm{PxB})$ tidak berpengaruh nyata, terhadap tinggi tanaman umur 15 hari setelah tanam.

Hasil uji BNT taraf 5\% pada perlakuan pupuk biorganik (P) menunjukkan bahwa perlakuan $\mathrm{p}_{0}, \mathrm{p}_{1}, \mathrm{p}_{2}$ dan $\mathrm{p}_{3}$ satu sama lainnya saling tidak berbeda nyata. Hasil uji BNT taraf 5\% pada perlakuan pupuk boom flower (B) menunjukkan bahwa perlakuan $b_{2}$ tidak berbeda nyata dengan perlakuan $p_{1}$, tetapi berbeda nyata dengan perlakuan $\mathrm{p}_{0}$. Perlakuan $\mathrm{p}_{1}$ tidak berbeda nyata dengan perlakuan $\mathrm{p}_{0}$

\subsection{Tinggi Tanaman Umur 30 Hari Setelah Tanam}

Hasil sidik ragam menunjukkan bahwa perlakuan pupuk biorganik (P) berpengaruh sangat nyata, sedangkan perlakuan pupuk boom flower (B) dan interaksinya $(\mathrm{PxB})$ tidak berpengaruh nyata terhadap tinggi tanaman umur 30 hari setelah tanam.

Hasil uji BNT taraf 5\% pada perlakuan pupuk biorganik (P) menunjujjan bahwa perlakuan $\mathrm{p}_{3}$ tidak berbeda nyata dengan perlakuan $\mathrm{p}_{2}$, tetapi berbeda nyata dengan perlakuan $\mathrm{p}_{1}$ dan $\mathrm{p}_{0}$. Perlakuan $\mathrm{p}_{2}$ tidak berbeda nyata dengan perlakuan $\mathrm{p}_{1}$, tetapi berbeda nyata dengan perlakuan $\mathrm{p}_{0}$. Perlakuan $\mathrm{p}_{1}$ berbeda nyata dengan perlakuan $\mathrm{p}_{0}$.

\subsection{Tinggi Tanaman Umur 45 Hari Setelah Tanam}

Hasil sidik ragam menunjukkan bahwa perlakuan pupuk biorganik $(\mathrm{P})$ berpengaruh sangat nyata, sedangkan perlakuan pupuk boom flower (B), serta interaksinya $(\mathrm{PxB})$ tidak berpengaruh nyata terhadap tinggi tanaman umur 45 hari setelah tanam.

Hasil uji BNT taraf 5\% pada perlakuan pupuk biorganik $(\mathrm{P})$ menunjujjan bahwa perlakuan $\mathrm{p}_{3}$ berbeda nyata dengan perlakuan $\mathrm{p}_{2}, \mathrm{p}_{1}$ dan $\mathrm{p}_{0}$. 
Perlakuan $\mathrm{p}_{2}$ tidak berbeda nyata dengan perlakuan $\mathrm{p}_{1}$, tetapi berbeda nyata dengan perlakuan $\mathrm{p}_{0}$. Perlakuan $\mathrm{p}_{1}$ berbeda nyata dengan perlakuan $\mathrm{p}_{0}$.

\subsection{Umur Saat Berbunga (hari)}

Hasil sidik ragam menunjukkan bahwa perlakuan pupuk biorganik $(\mathrm{P})$ dan interaksinya $(\mathrm{PxB})$ tidak berpengaruh nyata, sedangkan perlakuan pupuk boom flower (B) berpengaruh sangat nyata terhadap umur saat berbunga.

Hasil uji BNT taraf 5\% pada perlakuanpupuk boom flower (B) menunjukkan bahwa perlakuan $b_{2}, b_{1}$ dan $\mathrm{b}_{0}$ satu sama lainnya saling berbeda nyata.

\subsection{Jumlah Buah Per Tanaman (buah)}

Hasil sidik ragam menunjukkan bahwa perlakuan pupuk biorganik (P) berpengaruh sangat nyata, dan perlakuan pupuk boom flower (B) berpengaruh nyata, sedangkan interaksinya (PxB) tidak berpengaruh nyata terhadap jumlah buah per tanaman (Tabel 2). biorganik (P) menunjujjan bahwa perlakuan $\mathrm{p}_{3}, \mathrm{p}_{2}, \mathrm{p}_{3}$ dan $\mathrm{p}_{0}$ satu sama lainnya saling berbeda nyata.

Hasil uji BNT taraf 5\% pada perlakuan pupuk boom flower (B) menunjukkan bahwa perlakuan $b_{2}$ tidak berbeda nyata dengan perlakuan $b_{1}$, tetapi berbeda nyata dengan perlakuan $b_{0}$. Perlakuan $b_{1}$ tidak berbeda nyata dengan perlakuan $b_{0}$.

\subsection{Berat Buah Per Tanaman (kg)}

Hasil sidik ragam menunjukkan bahwa perlakuan pupuk biorganik (P), dan pupuk boom flower (B) berpengaruh sangat nyata, sedangkan interaksinya (PxB), tidak berpengaruh nyata terhadap berat buah per tanaman.

Hasil uji BNT taraf 5\% pada perlakuan pupuk biorganik (P) menunjukkan bahwa perlakuan $\mathrm{p}_{3}, \mathrm{p}_{2}, \mathrm{p}_{1}$ dan $\mathrm{p}_{0}$ satu sama lainnya saling berbeda nyata.

Hasil uji BNT taraf 5\% pada perlakuan pupuk boom flower (B) menunjukkan bahwa perlakuan $b_{2}$ tidak berbeda nyata dengan perlakuan $b_{1}$, tetapi berbeda nyata dengan perlakuan $b_{0}$. Perlakuan $b_{1}$ berbeda nyata dengan perlakuan $b_{0}$.

Hasil uji BNT taraf 5\% pada interaksi perlakuan pupuk biorganik dan pupuk boom flower (PxB) menunjukkan bahwa perlakuan $p_{3} b_{2}, p_{3} b_{0}$ dan $p_{3} b_{1}$ tidak berbeda nyata dengan perlakuan $\mathrm{p}_{2} \mathrm{~b}_{1}$ dan $\mathrm{p}_{2} \mathrm{~b}_{2}$, tetapi berbeda nyata dengan perlakuan $\mathrm{p}_{1} \mathrm{~b}_{2}, \mathrm{p}_{2} \mathrm{~b}_{0}, \mathrm{p}_{1} \mathrm{~b}_{1}, \mathrm{p}_{2} \mathrm{~b}_{2}, \mathrm{p}_{1} \mathrm{~b}_{0}, \mathrm{p}_{0} \mathrm{~b}_{1}$ dan $\mathrm{p}_{0} \mathrm{~b}_{0}$. Perlakuan $\mathrm{p}_{2} \mathrm{~b}_{1}$ tidak berbeda nyata dengan perlakuan $\mathrm{p}_{2} \mathrm{~b}_{2}$ dan $\mathrm{p}_{1} \mathrm{~b}_{2}$, tetapi berbeda nyata dengan perlakuan $\mathrm{p}_{2} \mathrm{~b}_{0}, \mathrm{p}_{1} \mathrm{~b}_{1}, \mathrm{p}_{2} \mathrm{~b}_{2}, \mathrm{p}_{1} \mathrm{~b}_{0}, \mathrm{p}_{0} \mathrm{~b}_{1}$ dan $\mathrm{p}_{0} \mathrm{~b}_{0}$. Perlakuan $\mathrm{p}_{2} \mathrm{~b}_{2}$ dan $\mathrm{p}_{1} \mathrm{~b}_{2}$ tidak berbeda nyata dengan perlakuan $\mathrm{p}_{2} \mathrm{~b}_{0}$ dan $\mathrm{p}_{1} \mathrm{~b}_{1}$, tetapi berbeda nyata dengan perlakuan $\mathrm{p}_{2} \mathrm{~b}_{2}, \mathrm{p}_{1} \mathrm{~b}_{0}, \mathrm{p}_{0} \mathrm{~b}_{1}$ dan $\mathrm{p}_{0} \mathrm{~b}_{0}$. Perlakuan $\mathrm{p}_{2} \mathrm{~b}_{0}$ dan $\mathrm{p}_{1} \mathrm{~b}_{1}$ tidak berbeda nyata dengan perlakuan $\mathrm{p}_{2} \mathrm{~b}_{2}, \quad \mathrm{p}_{1} \mathrm{~b}_{0}, \mathrm{p}_{0} \mathrm{~b}_{1}$ dan $\mathrm{p}_{0} \mathrm{~b}_{0}$. Perlakuan $\mathrm{p}_{2} \mathrm{~b}_{2}, \mathrm{p}_{1} \mathrm{~b}_{0}, \mathrm{p}_{0} \mathrm{~b}_{1}$ dan $\mathrm{p}_{0} \mathrm{~b}_{0}$ satu sama lainnya saling tidak berbeda nyata.

Tabel 2. Rekapitulasi Data Penelitian Pengaruh Pupuk Biorganik dan Pupuk Boom Flower Terhadap Pertumbuhan dan Hasil Tanaman Terung (Solanum melongena L.) Varietas Laguna F1.

\begin{tabular}{|c|c|c|c|c|c|c|}
\hline \multirow[b]{2}{*}{ Faktor Perlakuan } & \multicolumn{3}{|c|}{ Tinggi Tanaman $(\mathrm{cm})$} & Umur & Jumlah & Berat \\
\hline & 15 HST & $30 \mathrm{HST}$ & 45 HST & $\begin{array}{l}\text { Berbunga } \\
\text { (hari) }\end{array}$ & $\begin{array}{l}\text { Tanaman } \\
\text { (buah) }\end{array}$ & $\begin{array}{l}\text { Tanaman } \\
(\mathrm{kg})\end{array}$ \\
\hline
\end{tabular}




\begin{tabular}{|c|c|c|c|c|c|c|}
\hline $\begin{array}{l}\text { Pupuk } \\
\text { Biorganik } \\
\text { (P) } \\
\text { Sidik Ragam }\end{array}$ & $* *$ & $* *$ & $* *$ & tn & $* *$ & $* *$ \\
\hline $\mathrm{p} 0$ & $10,67 \mathrm{~d}$ & $36,50 \mathrm{c}$ & $56,42 \mathrm{c}$ & 32,92 & $9,67 \mathrm{~d}$ & $1,84 \mathrm{~d}$ \\
\hline $\mathrm{p} 1$ & $11,92 \mathrm{c}$ & $38,67 \mathrm{~b}$ & $64,17 \mathrm{~b}$ & 31,50 & $12,33 \mathrm{c}$ & $2,55 \mathrm{c}$ \\
\hline $\mathrm{p}_{2}$ & $13,08 \mathrm{~b}$ & $39,50 \mathrm{ab}$ & $65,00 \mathrm{~b}$ & 31,08 & $13,50 \mathrm{~b}$ & $3,04 \mathrm{~b}$ \\
\hline $\mathrm{p}_{3}$ & $15,67 \mathrm{a}$ & $40,92 \mathrm{a}$ & $71,33 \mathrm{a}$ & 31,42 & $14,83 \mathrm{a}$ & $3,31 \mathrm{a}$ \\
\hline $\begin{array}{l}\text { Pupuk } \\
\text { Suplemen } \\
\text { Boom } \\
\text { Flower (B) } \\
\text { Sidik Ragam }\end{array}$ & $*$ & tn & tn & $* *$ & $*$ & $* *$ \\
\hline $\mathrm{b} 0$ & $12,38 \mathrm{~b}$ & 38,56 & 63,31 & $34,44 \mathrm{c}$ & $11,81 \mathrm{~b}$ & $2,44 \mathrm{~b}$ \\
\hline b1 & $12,81 \mathrm{ab}$ & 39,00 & 63,88 & $31,19 b$ & $12,69 \mathrm{ab}$ & $2,76 \mathrm{a}$ \\
\hline $\mathrm{b} 2$ & $13,31 \mathrm{a}$ & 39,13 & 65,50 & $29,56 \mathrm{a}$ & $13,13 \mathrm{a}$ & $2,79 \mathrm{a}$ \\
\hline $\begin{array}{l}\text { Interaksi } \\
(\mathrm{BxP}) \\
\text { Sidik Ragam }\end{array}$ & tn & tn & tn & tn & tn & $*$ \\
\hline p0b0 & 10,00 & 36,25 & 53,75 & 36,00 & 9,00 & $1,68 \mathrm{~d}$ \\
\hline p0b1 & 11,00 & 36,25 & 55,75 & 32,75 & 9,25 & $1,78 \mathrm{~d}$ \\
\hline p0b2 & 11,00 & 37,00 & 59,75 & 30,00 & 10,75 & $2,05 \mathrm{~d}$ \\
\hline $\mathrm{p} 1 \mathrm{~b} 0$ & 11,75 & 38,25 & 63,75 & 34,00 & 10,75 & $2,01 \mathrm{~d}$ \\
\hline plb1 & 11,75 & 38,75 & 63,00 & 30,75 & 13,50 & $2,79 \mathrm{c}$ \\
\hline $\mathrm{p} 1 \mathrm{~b} 2$ & 12,25 & 39,00 & 65,75 & 29,75 & 12,75 & $2,85 \mathrm{bc}$ \\
\hline $\mathrm{p} 2 \mathrm{~b} 0$ & 13,00 & 39,75 & 66,00 & 33,50 & 12,50 & $2,80 \mathrm{c}$ \\
\hline $\mathrm{p} 2 \mathrm{~b} 1$ & 13,00 & 39,50 & 65,25 & 30,50 & 14,25 & $3,21 \mathrm{ab}$ \\
\hline $\mathrm{p} 2 \mathrm{~b} 2$ & 13,25 & 39,25 & 63,75 & 29,25 & 14,00 & $3,10 \mathrm{abc}$ \\
\hline p3b0 & 14,75 & 40,00 & 69,75 & 34,25 & 15,00 & $3,28 \mathrm{a}$ \\
\hline p3b1 & 15,50 & 41,50 & 71,50 & 30,75 & 13,75 & $3,25 \mathrm{a}$ \\
\hline p3b2 & 16,75 & 41,25 & 72,75 & 29,26 & 15,00 & $3,41 \mathrm{a}$ \\
\hline
\end{tabular}

\section{Keterangan :}

* : berpengaruh nyata

**: berpengaruh sangat nyata

tn : tidak berpengaruh nyata

HST : Hari Setelah Tanam $\mathrm{p}_{0}$ : tanpa pupuk biorganik atau kontrol

$\mathrm{p}_{1}$ : dosis pupuk biorganik $25 \mathrm{~g} /$ polibag

$\mathrm{p}_{2}$ : dosis pupuk biorganik $50 \mathrm{~g} /$ polibag

$\mathrm{p}_{3}$ : dosis pupuk biorganik $75 \mathrm{~g} /$ polibag

$\mathrm{b}_{0}$ : tanpa pupuk boom flower atau kontrol

$\mathrm{b}_{1}$ : konsentrasi pupuk boom flower $2 \mathrm{ml} / \mathrm{l}$.air

$b_{2}$ : konsentrasi pupuk boom flower $4 \mathrm{ml} / \mathrm{l}$.air
Pengaruh Pupuk Biorganik Terhadap Pertumbuhan dan Hasil Tanaman Terung (Solanum melongena L.) Varietas Laguna F1. Hasil sidik ragam menunjukkan bahwa perlakuan pupuk biorganik tidak berpengaruh nyata terhadap umur saat berbunga. Berpengaruh sangat nyata terhadap tinggi tanaman umur 15 hari, umur 30 hari dan umur 45 hari setelah tanam, jumlah buah per tanaman dan 
berat buah per tanaman (Tabel 2). Hasil penelitian menunjukkan bahwa pemberian pupuk biorganik mampu meningkatkan pertumbuhan tanaman seperti tinggi, jumlah buah per tanaman dan berat buah per tanaman. Semakin meningkat dosis pupuk yang diberikan, semakin meningkat pula pertumbuhan tanaman. Pengaruh perlakuan pupuk biorganik dengan dosis $75 \mathrm{~g} /$ polibag secara umum lebih baik dibandingkan dengan perlakuan tanpa pupuk atau kontrol.

Tinggi tanaman tertinggi terdapat pada perlakuan pupuk biorganik dengan dosis $75 \mathrm{~g} /$ polibag pada umur 15 hari, umur 30 hari dan 45 hari setelah tanam, yaitu secara berurutan adalah $15,67 \mathrm{~cm}$, dan $40,92 \mathrm{~cm}$ dan $71,33 \mathrm{~cm}$, sedangkan yang terendah terdapat pada perlakuan tanpa pupuk biorganik (kontrol), yaitu secara berturutan adalah : $10,67 \mathrm{~cm}$, 36,50 dan $56,42 \mathrm{~cm}$.

Hal ini menunjukkan bahwa pemberian pupuk biorganik yang diberikan bermanfaat untuk meningkatkan pertumbuhan tanaman. Semakin meningkat dosis pupuk biorganik yang diberikan akan menyebabkan meningkatnya ketersediaan unsur hara didalam tanah. Pertumbuhan tanaman dipengaruhi oleh ketersediaan unsur hara di dalam tanah dan juga pupuk yang diaplikasikan ke dalam tanah. Menurut Darmawan dan Baharsyah (2010), bahwa pertumbuhan merupakan pertambahan dari jumlah dan dimensi tanaman, baik tinggi tanaman, jumlah buah dan berat buah. Hal ini juga sesuai dengan manfaat pupuk biorganik, yaitu merangsang pertumbuhan akar, batang dan daun (Agromedia, 2007). Hasil analisis tanah di Laboratorium menunjukkan bahwa $\mathrm{pH}$ tanah 4,57 (masam), C-organik 1,77\% (rendah), N-total 0,22\% (sedang), C/N rasio 8,01\% (rendah), P-tersedia 5,27 ppm (sangat rendah) dan K-tersedia 13,95 (rendah). Hal ini menunjukkan bahwa walaupun kondisi media tanah $\mathrm{pH}$-nya masam dan kandungan unsur haranya rendah, tetapi dengan pemberian pupuk biorganik, maka terjadi peningkatan pertumbuhan dan hasil tanaman terung. Karena tersedianya jumlah unsur hara di dalam tanah, sehingga mudah diserap oleh akar tanaman, dan akhirnya meningkatkan pertumbuhan tinggi tanaman. Hasil Penelitian analisa tanah di Desa Giri Agung KTK kebanyakan rendah, adapun KTK yang rendah dapat ditingkatkan dengan penggunaan pupuk organik yang berguna untuk meningkatkan tanah menjadi gembur dan daya jerap tanah dan untuk meningkatkan kapasitas tukar kation sehingga dapat menampung apabila dilakukan penambahan unsur hara baik secara alami maupun dengan penambahan pupuk (Datu BP et al., 2013). Selanjutnya pemupukan ditentukan oleh keadaan tanah seperti tanah-tanah pada lokasi studi menunjukkan reaksi tanah masam perlu dilakukan pemberian kapur (I Gede EB et al., 2017).

Pada parameter umur saat berbunga, perlakuan pupuk biorganik tidak berpengaruh nyata, hal ini diduga bahwa kandungan unsur hara yang ada di dalam pupuk biorganik relatif rendah, terutama unsur $\mathrm{P}$ dan $\mathrm{K}$ yang mempunyai peran dalam pertumbuhan generatif. Aadapun komposisi unsur hara dalam pupuk biorganik, yaitu : $\mathrm{N}_{2}(1,1 \%) ; \mathrm{P}_{2} \mathrm{O}_{5}$ $(1,7 \%) ; \mathrm{K}_{2} \mathrm{O}(0,5 \%)$.

Pada fase pertumbuhan generatif, terutama jumlah buah dan berat buah tanaman terung, perlakuan pupuk biorganik berpengaruh sangat nyata. Jumlah buah terbanyak dan berat buah terberat per tanaman terdapat pada perlakuan pupuk biorganik dengan dosis $75 \mathrm{~g} /$ polibag, yaitu 14,83 buah/tanaman dan 3,31 kg/tanaman. Sedangkan jumlah buah paling sedikit dan berat buah teringan terdapat pada perlakuan tanpa pupuk biorganik atau kontrol, yaitu 9,67 
buah/tanaman dan 1,84 kg/tanaman. Hasil penelitian menunjukkan bahwa perlakuan pupuk kandang sapi untuk semua parameter : tinggi tanaman 15,30 , dan 45 hari setelah tanam, jumlah buah per tanaman, panjang buah, diameter buah, berat buah per tanaman, berat satu buah menunjukkan nilai tertinggi 500 gr/tanaman (Hendri, dkk., 2015). Penggunaan pupuk organik yang tepat dapat meningkatkan hasil yaitu jumlah buah dapat mencapai 9,96 buah dengan pemberian pupuk organic cair 9 mili (Prastya, Y. dan Puspitorini, P. 2017). Hasil penelitian dari berbagai dosis pupuk organik dan kombinasi pupuk N, $\mathrm{P}$ dan $K$ yang telah dicobakan, pertumbuhan dan hasil tanaman terung yang terbaik dijumpai pada perlakuan dosis bahan orgnik 40\% (D2) dan kombinasi pupuk $\mathrm{N}, \mathrm{P}$ dan $\mathrm{K}$ K2 (Urea $200 \mathrm{~kg}+\mathrm{SP} 36100 \mathrm{~kg}+\mathrm{KCl} 50 \mathrm{~kg} / \mathrm{ha})$ dengan jumlah buah pertanaman 19,98 dan berat buah pertanaman 6,657 g (Rina, dkk., 2019).

Pengaruh Pupuk Boom Flower Terhadap Pertumbuhan dan Hasil Tanaman Terung (Solanum melongena L.) Varietas Laguna F1. Hasil sidik ragam menunjukkan bahwa perlakuan pupuk Boom Flower berpengaruh nyata terhadap tinggi tanaman 15 hari setelah tanam tapi tidak berpengaruh nyata terhadap tinggi tanaman umur 30 hari dan 45 hari. Berpengaruh sangat nyata terhadap umur saat berbunga (Tabel 2).

Hasil penelitian menunjukkan bahwa pemberian pupuk boom flower Berpengaruh sangat nyata terhadap umur saat berbunga, Berat buah per Tanaman, dan berpengaruh nyata terhadap jumlah buah per tanaman. Pengaruh pemberian pupuk boom flowerdengan dosis (b2) 4ml/1.air berpengaruh sangat nyata terhadap umur saat berbunga yaitu 29,56 hari dan dengan dosis (b1)2ml/1.air yaitu 31,15 hari setelah tanam .secara umum lebih baik dibandingkan dengan perlakuan tanpa pupuk atau kontrol yaitu 34,44 hari setelah tanam.

Hal ini menunjukkan bahwa pemberian pupuk boom flower yang diberikan bermanfaat untuk pertumbuhan generatif tanaman, Kandungan unsur yang terdapat pada Boom Flower : C organik 6,89\%, P2O5 27 ppm, K2O, 13 ppm, Fe 6 ppm, Mn 2 ppm, Zn I ppm dan B 51 ppm (Sarana Agri, 2016). yaitu unsur $\mathrm{P}_{2} 0_{5}: 27$ ppm mempengaruhi masa pembungaan dan panen. Seperti yang dikemukakan oleh Novizan (2002), bahwa unsur fosfor $(\mathrm{P})$ dapat merangsang pertumbuhan bunga, buah, dan biji. Sedangkan unsur kalium peraanannya berhubungan dengan proses metabolisme, seperti fotosintesis dan respirasi.

Pengaruh Interaksi Perlakuan Pupuk Biorganik dan Pupuk Boom Flower Terhadap Pertumbuhan dan Hasil Tanaman Terung (Solanum melongena L.) Varietas Laguna F1. Hasil sidik ragam menunjukkan bahwa interaksi perlakuan antara pupuk Biorganik dan Pupuk Boom Flower tidak berpengaruh nyata terhadap parameter tinggi tanaman, Umur Saat Berbunga, dan Jumlah Buah Per Tanaman, Berpengaruh nyata terhadap Berat Buah Per Tanaman (Tabel 2). Secara umum interaksi perlakuan pupuk Biorganik dan Pupuk Boom Flower tidak memberikan hasil yang signifikan pada parameter penelitian yang diamati, tetapi ada kecenderungan pada Berat Buah Per Tanaman. Berat Buah Per Tanaman Tertinggi terdapat pada interaksi p3b2 (dosis pupuk Biorganik 75g/tanaman dan Pupuk Boom Flower 4 $\mathrm{ml} / 1$.air), yaitu $3,41 \mathrm{~kg} /$ tanaman. Hasil penelitian ini berbeda bila dibandingkan dengan deskripsi Terung varietas Laguna F1, yaitu 2-2,5 kg/buah (Tabel 2).

Capaian hasil berat buah per tanaman sebesar $1,84 \mathrm{~kg}$ s/d 3,31 kg. pada perlakuan pupuk Biorganik (P) dan antara 2,49 kg s/d 2,79 kg pada perlakuan pupuk Boom Flower (B) serta antara 1,68kg s/d 
3,41 kg pada perlakuan interaksi Pupuk Biorganik (P) \& Pupuk Boom Flower (B) semuanya masih sesuai dengan potensi berat buah per tanaman sebagaimana dalam deskripsi tanaman terung varietas Laguna F1 (Tabel 2).

Untuk parameter jumlah buah per tanaman capaian perlakuan interaksi Pupuk Biorganik (P) \& Pupuk Boom Flower (B) masih lebih sedikit dibandingkan dengan jumlah buah sebagaimana dalam Deskripsi Tanaman Terung varietas Laguna F1 (Tabel 2). Hal ini terjadi karena pada saat terjadi pembungaan kondisi dilapangan dengan curah hujan yang tinggisehingga banyak bunga yang gugur dan gagal menjadi buah.

\section{KESIMPULAN}

Berdasarkan hasil penelitian, maka dapat disimpulkan sebagai nerikut : Perlakuan pupuk biorganik tidak berpengaruh nyata terhadap umur saat berbunga. Berpengaruh sangat nyata terhadap tinggi tanaman umur 15 hari, umur 30 hari dan umur 45 hari setelah tanam, jumlah buah per tanaman dan berat buah per tanaman. Berat buah per tanaman terberat terdapat pada perlakuan $\mathrm{p}_{3}$ (dosis pupuk $75 \mathrm{~g} /$ polibag), yaitu 3,31 $\mathrm{kg}$ /tanaman. Sedangkan berat buah teringan terdapat pada perlakuan $\mathrm{p}_{0}$ (tanpa pupuk biorganik), yaitu 1,84 $\mathrm{kg} / \mathrm{tanaman}$.

Perlakuan pupuk boom flower tidak berpengaruh nyata terhadap tinggi tanaman umur 30 hari dan umur 45 hari setelah tanam. Berpengaruh nyata terhadap tinggi tanaman umur 15 hari setelah tanam dan jumlah buah per tanaman. Berpengaruh sangat nyata terhadap umur saat berbunga dan berat buah per tanaman. Berat buah per tanaman terberat terdapat pada perlakuan $\mathrm{b}_{2}$ (konsentrasi pupuk $4 \mathrm{ml}$ liter air $^{-1}$ ), yaitu $2,79 \mathrm{~kg} / \mathrm{tanaman}$. Sedangkan berat buah teringan terdapat pada perlakuan $\mathrm{b}_{0}$ (tanpa pupuk boom flower), yaitu 2,44 $\mathrm{kg} / \mathrm{tanaman}$.

Interaksi perlakuan pupuk biorganik dan pupuk boom flower tidak berpengaruh nyata terhadap tinggi tanaman umur 15 hari, umur 30 hari dan umur 45 hari setelah tanam, umur saat berbunga dan jumlah buah per tanaman. Berpengaruh nyata terhadap berat buah per tanaman. Berat buah per tanaman terberat terdapat pada perlakuan $\mathrm{p}_{3} \mathrm{~b}_{2}$ (dosis pupuk biorganik $75 \mathrm{~g} /$ polibag dan konsentrasi pupuk boom flower $4 \mathrm{ml}$ liter air $^{-1}$ ), yaitu 3,41 kg/tanaman. Sedangkan berat buah teringan terdapat pada perlakuan $\mathrm{p}_{0} \mathrm{~b}_{0}$ (tanpa pupuk biorganik dan pupuk boom flower), yaitu 2,44 $\mathrm{kg} / \mathrm{tanaman}$.

\section{DAFTAR PUSTAKA}

Agromedia, R. (2007). Petunjuk Pemupukan. Jakarta: Agromedia Pustaka.

BPS Kaltim. (2015). produksi-tanamansayur-sayuran-menurut-jenisnyaton-tahun-2011-2015. Diakses 20 Desember 2017, dari https://kaltim.bps.go.id/statictable/2 015/03/10/31

Budiana, I. G. E., Jumani., Biantary, M.P. (2017). Evaluation of Soil Revegetation Success Rate Ex-Pit Coal Mine in Kitadin site Embalut Kutai in East Kalimantan. Agrifor, 16(2), 195208.

Budiman. (2008). Respon Pertumbuhan Tanaman Terung. JUPEMASIPBIO.

Hendri, M., Napitupulu, M., \& Sujalu, A. P. (2015). Pengaruh pupuk kandang sapi dan pupuk NPK Mutiara terhadap pertumbuhan dan hasil 
tanaman terung ungu (Solanum melongena L.). Agrifor, 14(2), 213220.

Marsono dan Lingga, P. (2006). Petunjuk Penggunaan Pupuk. Jakarta: Penebar Swadaya.

Novizan. (2007). Petunjuk Pemupukan yang Efektif. Jakarta: Agromedia Pustaka.

Pramana, D. B. (2013). Pertumbuhan Tanaman Gaharu (Aquilaria sp.) di Desa Giri Agung Kecamatan Sebulu Kabupaten Kutai Kartanegara Provinsi Kalimantan Timur. Agrifor, 11(2), 110-114.

Prastya, Y., \& Puspitorini, P. (2017). Pengaruh Dosis Pupuk Kandang Sapi dan Pupuk Organik Cair Terhadap Pertumbuhan dan Hasil Tanaman Terung Ungu (Solanum melongena L.). VIABEL: Jurnal Ilmiah Ilmu-Ilmu Pertanian, 11(1), 23-34.
Rina, T., Marliah, A., \& Anhar, A. (2019). Pertumbuhan dan Hasil Tanaman Terung (Solanum melongena L.) Pada Berbagai Dosis Bahan Organik Dan Kombinasi Pupuk N, P dan K. Jurnal Ilmiah Mahasiswa Pertanian, 4(1), 100107.

Rukmana. (2006). Bertanam Terung. Yogyakarta: Penerbit Kanisius.

Samadi. (2011). Budidaya Terung Hibrida. Yogyakarta: Kanisius.

Sarana Agri . (2016). Buku Manual Boom Flower. Jakarta: Bina Guna Kimia.

Sarief. (1989). Fisika-Kimia Tanah Pertanian. Bandung: Pustaka Buana.

Steel, R. G. D. dan J. H. Torrie. (1993). Prinsip dan Prosedur Statistika (Pendekatan Biometrik). Penerjemah B. Sumantri. Jakarta: Gramedia Pustaka Utama. 